Iranian Quarterly Journal of Breast Disease 2018; 11(4):53.

\title{
The Effect of Light-Intensity Physical Activity on Lifestyle and Socio- cognitive Factors Affecting Sedentary Behavior in Breast Cancer Survivors in Isfahan City
}

Rafei Borujeni M: Department of Motor Behavior and Sport Management, Faculty of Sport Sciences, University of Isfahan, Isfahan, Iran

Nikoobin N: Department of Motor Behavior and Sport Management, Faculty of Sport Sciences, University of Isfahan, Isfahan, Iran

Goharian V: Department of Surgery, School of Medicine, Isfahan University of Medical Sciences, Isfahan, Iran

Corresponding Author: Mehdi Rafei Borujeni, m.rafei@spr.ui.ac.ir

\begin{abstract}
Introduction: Lifestyle improvement is one of the main strategies to increase treatment persistence in breast cancer survivors. The purpose of the present study was to determine the effect of a light-intensity physical activity program on Socio-cognitive factors that affect sedentary behavior and lifestyle in breast cancer survivors in Isfahan city.

Methods: Twenty-four female breast cancer survivors were recruited via convenience sampling and randomly assigned to experiment and control groups (12 subjects for each group). Both groups were assessed using Busschaert's context-specific sedentary behavior questionnaire and the Miller-Smith Lifestyle Assessment Inventory before and after the intervention. The light-intensity physical activity program was conducted for one month in the experimental group based on Australia's Physical Activity and Sedentary Behavior Guidelines for Adults. Data were analyzed using descriptive statistics including mean and standard deviation and inferential statistics including ANCOVA and MANCOVA with a significance level of 0.05 .
\end{abstract}

Results: There was a significant difference between the two groups in lifestyle and Sociocognitive factors affecting sedentary behavior (except for the sedentary behavior modelling) $(\mathrm{p}=0.001)$.

Conclusion: It seems that performing light physical exercises may improve the lifestyle and Socio-cognitive factors affecting sedentary behavior by changing key factors such as motivation and intrapersonal relationship in breast cancer survivors.

Keywords: Physical Activity, Socio-cognitive Factors, Sedentary Behavior, Lifestyle, Breast Cancer Survivors 


\title{
تاثير يك دوره فعاليت بدنى سبُك بر سبك زندكى و عوامل اجتماعى شناختى اثركذار بر بىتحر كى در بهبود يافتكان سرطان يستان شهر اصفهان
}

\author{
مهيدى رافعى بروجنى": كروه رفتار حركتى و مديريت ورزشى، دانشكده علوم ورزشى، دانشكاه اصفهان، اصفهان، ايران

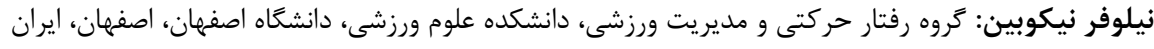

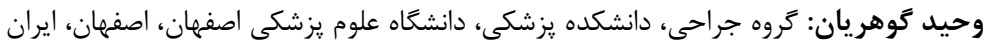

مقدمه: بهببود سبك زندگى يكى از مههمترين اقدامات در افزايش بقاى درمان در بهبود يافتكان از سرطان بستان مىباشد.

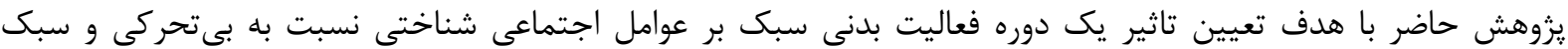

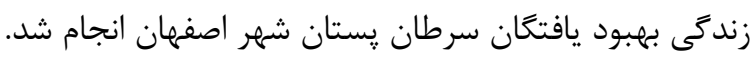

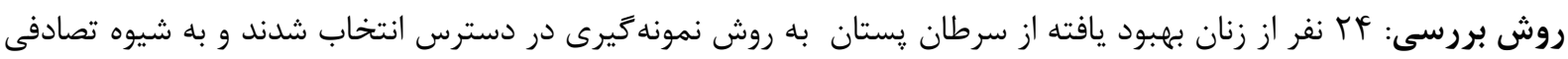

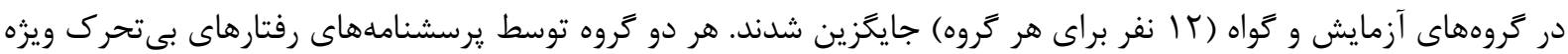

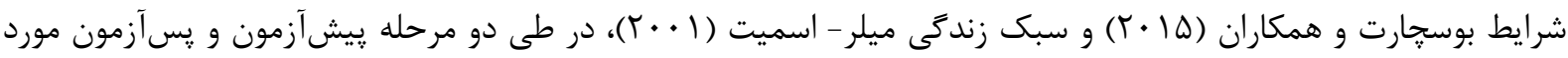

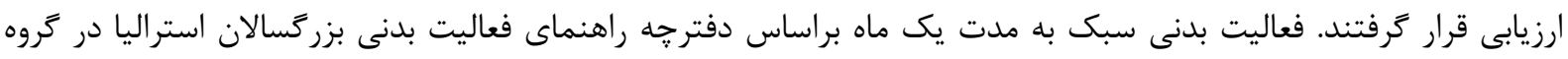
آزمايش اجرا شد. دادهها با استفاده از روشهاى آمار توصيفى ميانكين و انحراف استاندارد و آمار استنباطى شامل تحلى تحليل

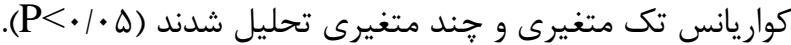

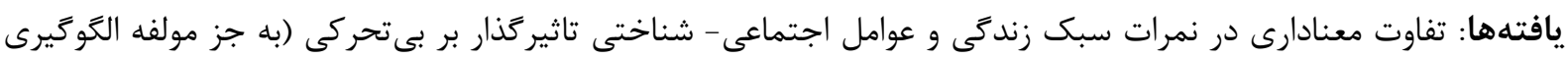

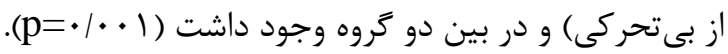

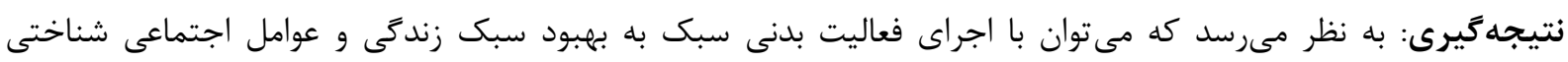

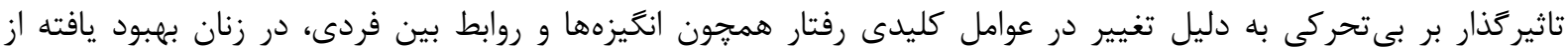
سرطان يستان كمك كرد. وازمهاى كليدى: فعاليت بدنى، عوامل اجتماعى شناختى، بى تحركى، سبك زندگى، بهبود يافتكان سرطان يستان 
كليدى رفتار مورد استفاده قرار مى گيرد، نظريه شناختى

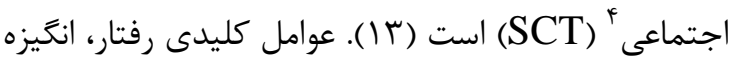
براى شركت در رفتارهاى مرتبط با سلامتى يا عوامل خطر آنا

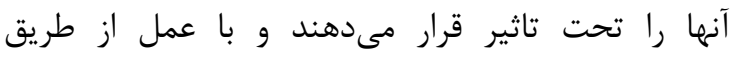
مكانيسمهاى مختلف نشان مىدهند كه عوامل شناختى اجتماعى مىتوانند تغييراتى در رفتارهاى بهداشتى مانند

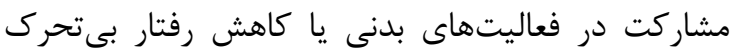

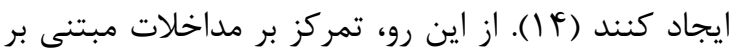
كسترش فعاليتهاى بدنى براى دستيابى به تغييرات عمده

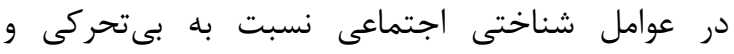

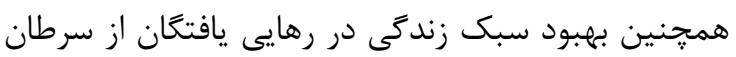
يستان ضرورى به نظر مىرسد. از جمله مداخلات مؤثر در اين زمينه كه در سالهاى اخدير

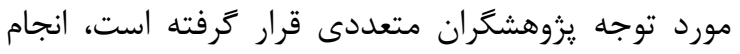
فعاليتهاى بدنى به ويزه فعاليتهاى بدنى سبك منى است

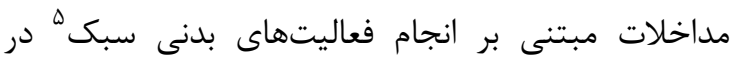

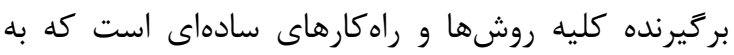

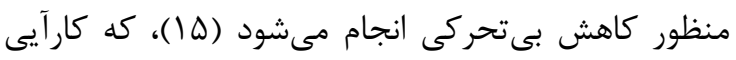

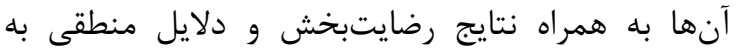
منظور استفاده از اين روش در برخى از مطالعات به تاييد

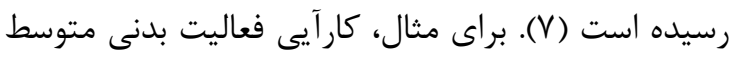
تا شديد بر عوامل شناختى اجتماعى نسبت به فيد فعاليت

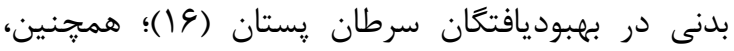

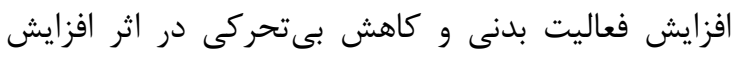

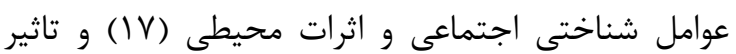
مداخله تغيير سبك زندگى (در زمينه فعاليت بدنى، تغذيه

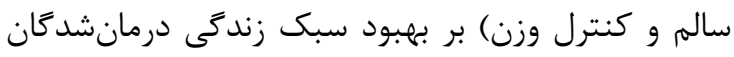
سرطان يستان (1) (1) مورد تاييد قرار كرفته است.

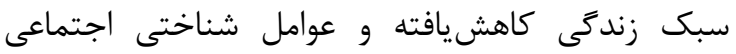

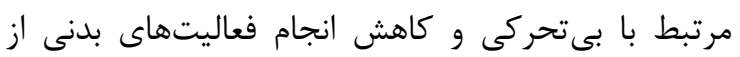

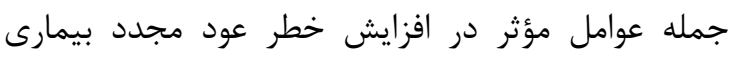

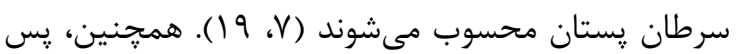
از اتمام و كذراندن مراحل درمانى، زنان بهبود يافته از

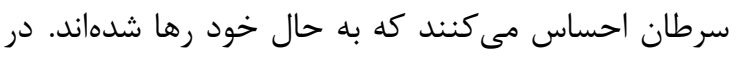

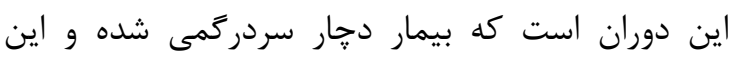
سؤال در ذهن وى شكل مى

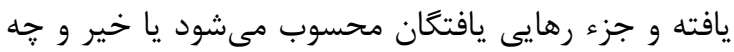

\footnotetext{
${ }^{4}$ Social cognitive theory

${ }^{5}$ Light intensity physical activity
}

يِيشرفت در تشخيص زودهنكام، انواع درمانها و كاربرد آنها موجب بقاى طولانىمدت و افزايش شانس زنده ماندن

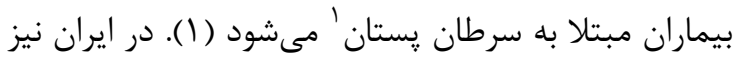

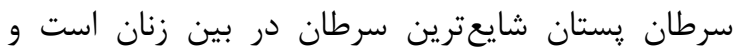

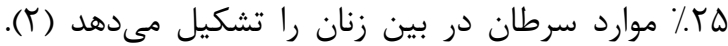

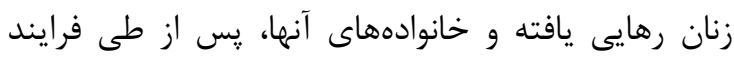

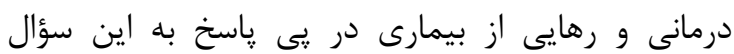

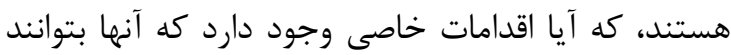

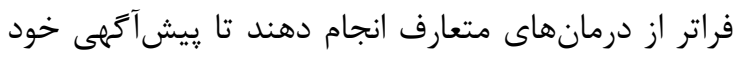

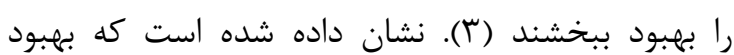

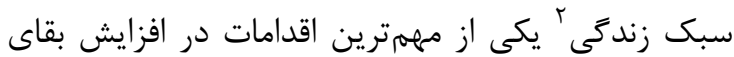

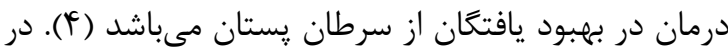

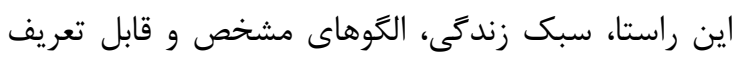

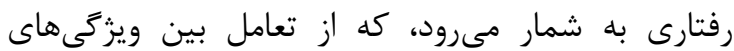
شخصى، روابط اجتماعى، شرايط محيطى و موقعيتهاى

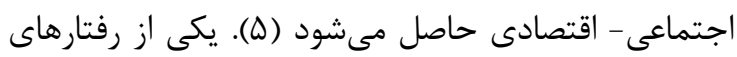

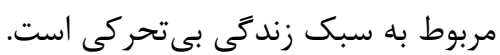

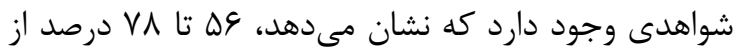

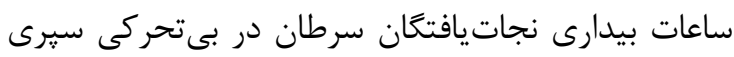

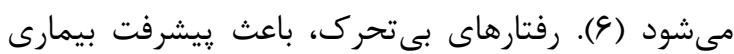
سرطان يستان و افزايش خطر عود مجدد سرطان يستان

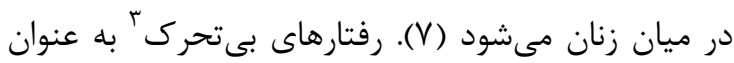
هر رفتارى در زمان بيدارى كه با مصرف انرزى بسى بسيار

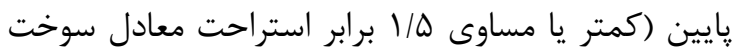

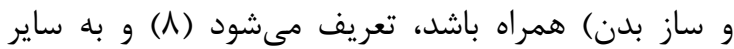

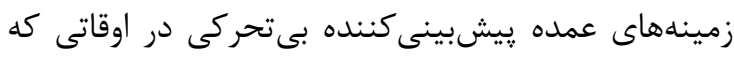

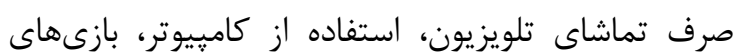
كامبيوترى و حمل و نقل ماشينى و بىتحركى شغلى نقلى مىشود، گسترش مى يابد (9، · (1). شواهد جديدتر نشان

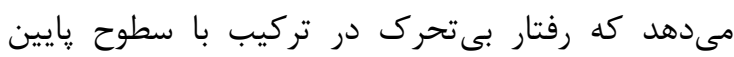
فعاليت بدنى، سبك زندگى يايينتر و توده بدنى ضعيفتر، مرك و مير در رهايى يافتخان سرطان يستان و ساير

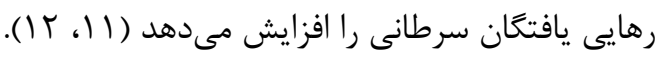
يكى از مدلهاى نظرى كه امروزه بيشتر براى بيشبي إنى

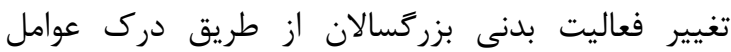

\footnotetext{
${ }^{1}$ Breast cancer

${ }^{2}$ Lifestyle

${ }^{3}$ Sedentary behaviors
} 
يا اختلالات شخصيت (بر اساس مندرجات يرونده يزشكى

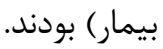

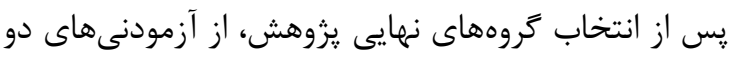

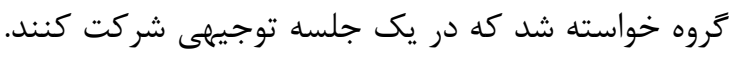
به منظور رعايت اصول اخلاقى، فرم موافقت براى

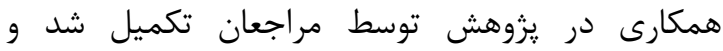

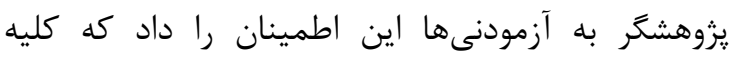

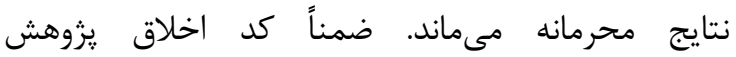
IR.UI.REC.1397.159 بود.

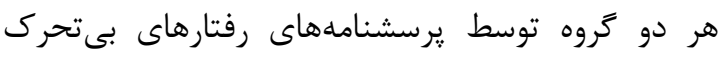

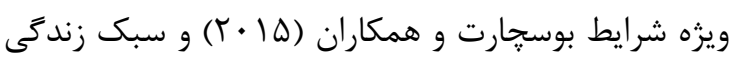

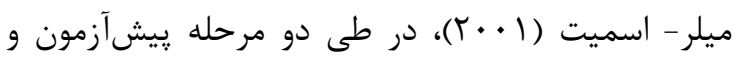
يس آزمون مورد ارزيابى قرار گرفتند. يرسشنامه رفتارهاى

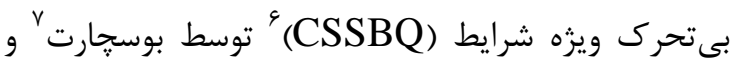

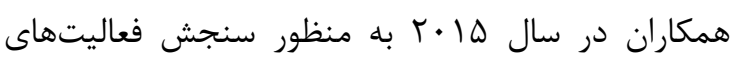

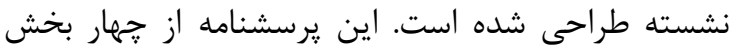

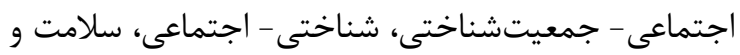

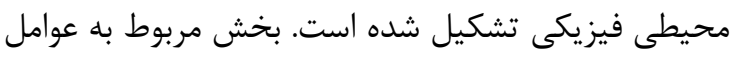

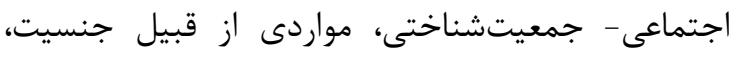

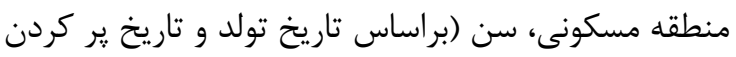

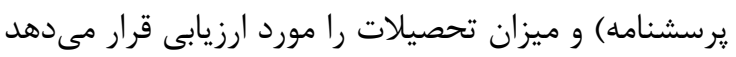

بخش مربوط به عوامل شناختى - اجتماعى، از 99 سؤال و

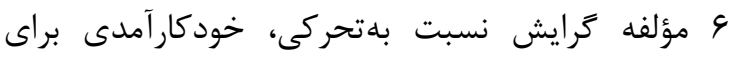

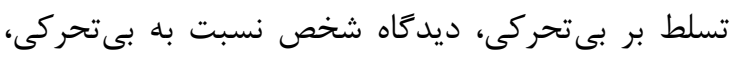

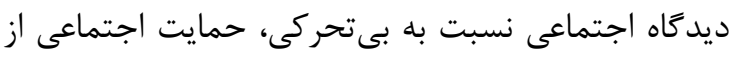

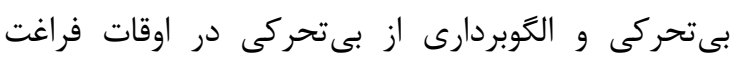

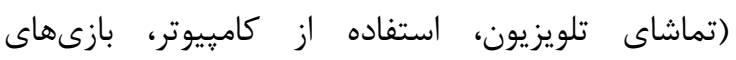
الكترونيكى و حمل و نقل ماشينى) تشكيل شده است.

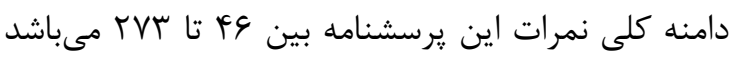

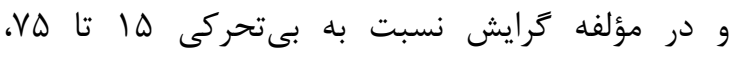

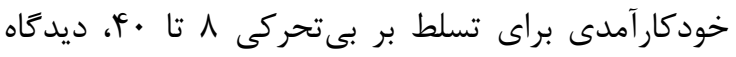

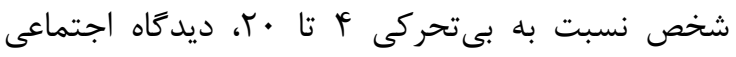

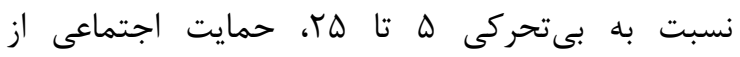

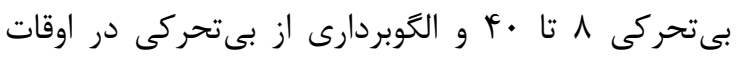

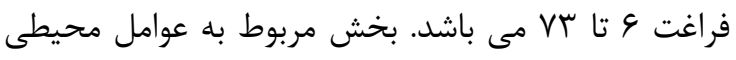
فيزيكى، تعداد دستكاههايى كه براى تماشاى تلويزيون،

\footnotetext{
${ }^{6}$ Context-Specific Sedentary Behaviour Questionnaires

${ }^{7}$ Busschaert
}

اقداماتى را بايد انجام دهد تا مجدداً سلامتى خود را باز

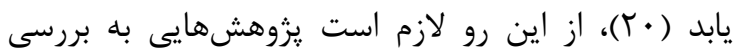

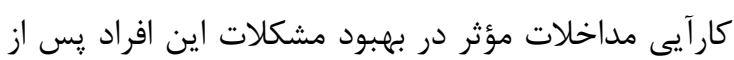

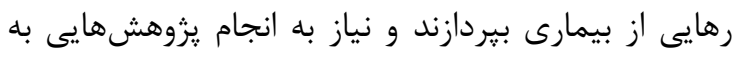
منظور تعيين اثربخشى مداخلاتى همجيون شركت در در انجام

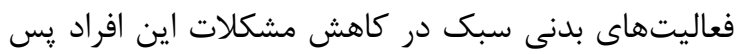

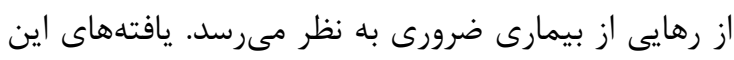

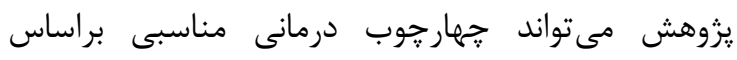

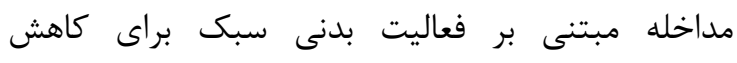

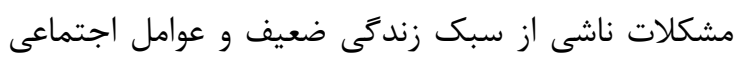

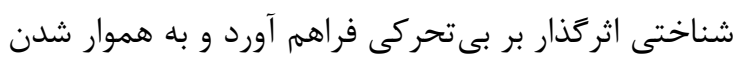

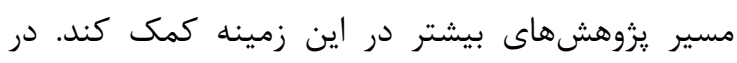

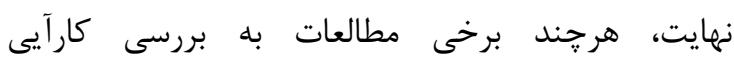

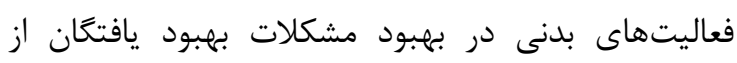

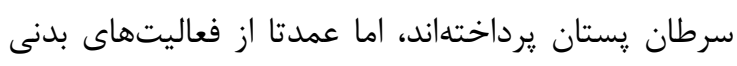

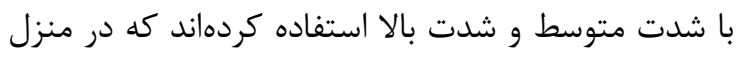

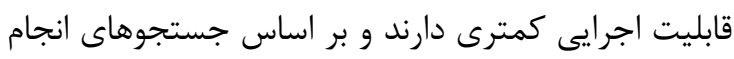

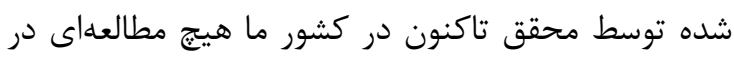

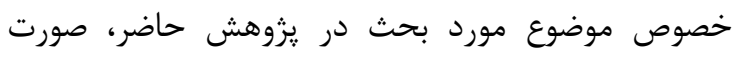

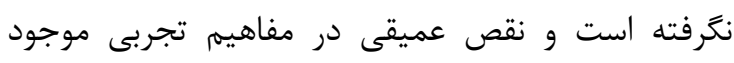

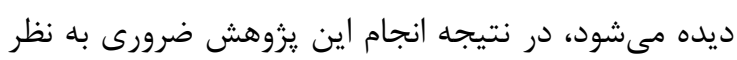

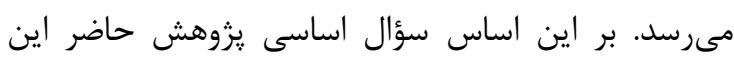

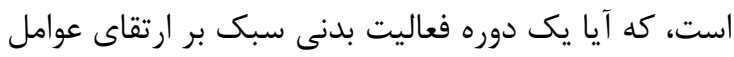

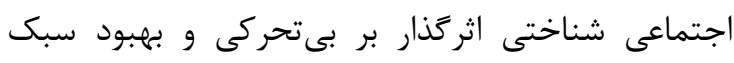

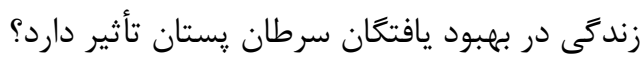

\section{مواد و روشها}

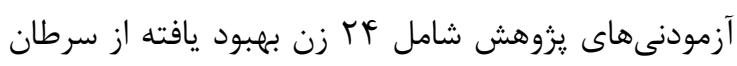
رِتان بودند كه با روش نمونه

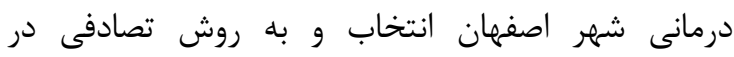

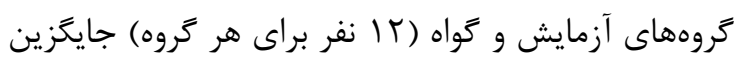

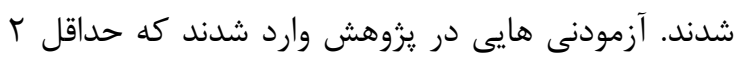

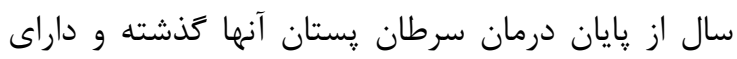

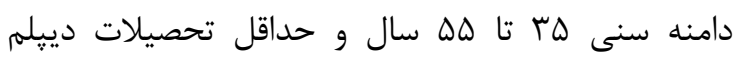

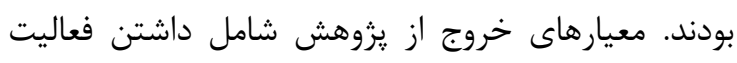

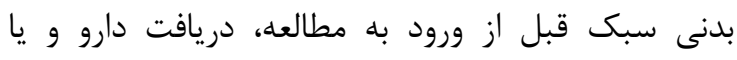

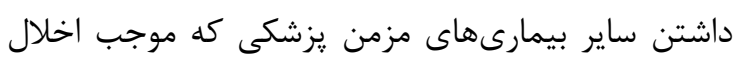

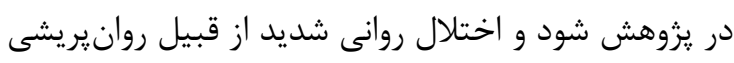


فعاليتهاى مربوط به زندكى روزمره را انجام مى فىادند. فعاليت بدنى سبك شامل توصيههايى براى افزايش فعاليت بدنى سبك در منزل كه دربر گيرنده فعاليتهاى روزانه بود (مثل اينكه براى روشن كردن تلويزيون از كنترل استفاده

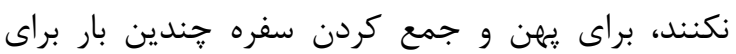

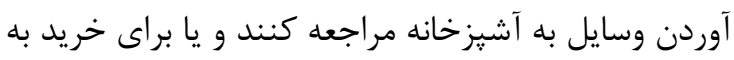
خارج از منزل بروند) و توصيه هاى مربوط به دفترجه

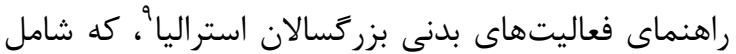

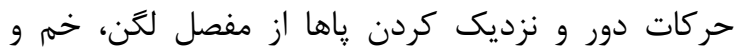
صاف كردن كمر، انتقال وزن روى انگشتان يا، بلند شدن و ورن نشستن روى صندلى بدون كمك، حركت شانهها به بالا و

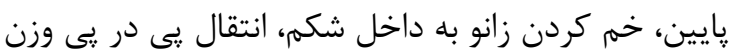

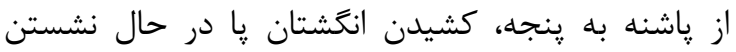
روى صندلى و با اتصال زياشنه به زمين، نشستن با ياى

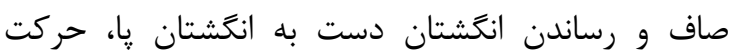
تعادل روى يك يا و راه رفتن به شيوه اتصال پاشنه پِاى

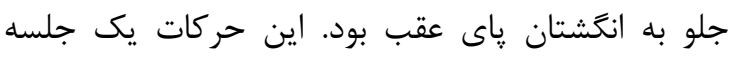

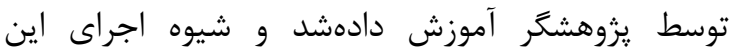
حركات همراه با عكس در اختيار آزمودنىها قرار گرفت كه

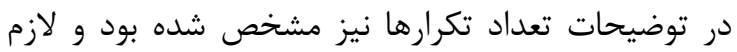

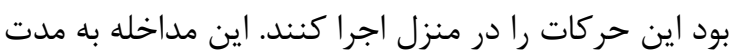

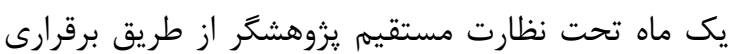
تماس تلفنى و نظارت حضورى اجرا شد. سيس يرسشنامههاى رفتارهاى بىتحرك ويزه شرايط بوسجارت

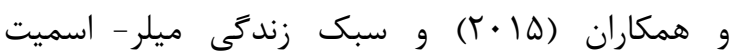
( ( . (Y)، در يسآزمون به آزمودنىها داده شد. روش تحليل دادههاى تحقيق: براى تحليل دادهاى يزوهش از روشهاى آمار توصيفى شامل درصد و فراوانى،

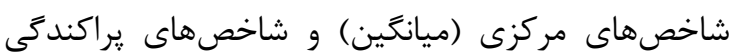
(انحراف معيار) و از آمار استنباطى شامل تحليل

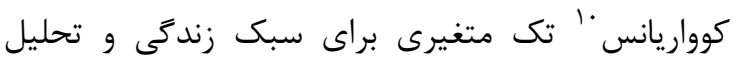

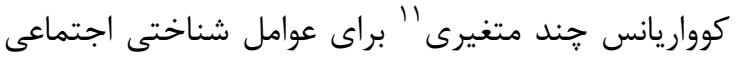

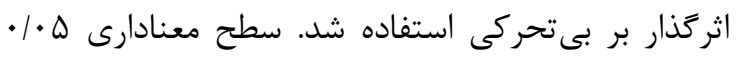

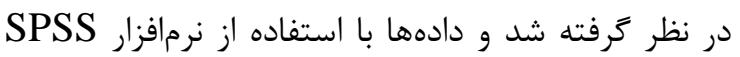
نسخه ال مورد تجزيه و تحليل قرار زرفتند.

\footnotetext{
${ }^{9}$ Physical activity guide for older Australians

استفاده از كامييوتر و بازىهاى الكترونيكى در خانه موجود است را در برمى گيرد، علاوه بر اين، سه متغير محيطى بلى فيزيكى اضافى در زمينه تماشاى تلويزيون دربرگيرنده

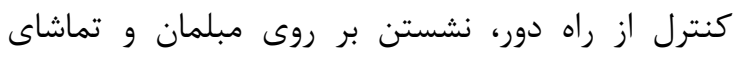

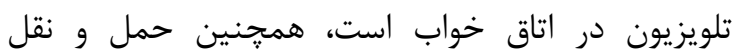
ماشينى براساس سؤالات بسته- ياسخ و باز - ياسخ مورد

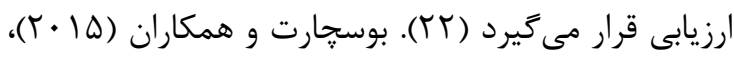
يايايى كل يرسشنامه را در بزرگسالان با استفاده از روش

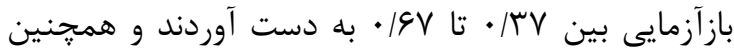
روايى محتوايى يرسشنامه را، مطلوب گزارش كردند ( آY).

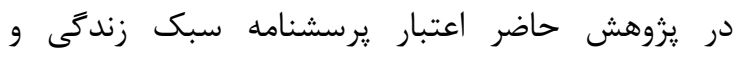
رفتارهاى بىتحرك ويزه شرايط از طريق روش اعتبار محتوا ارزيابى شد؛ به اين ترتيب كه يرسشنامههاى مذكور در دو مرحله توسط اساتيد روانشناسى در دانشكده

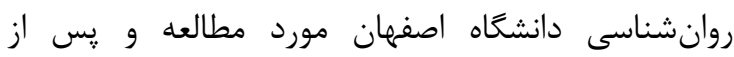
اصلاحات لازم از نظر مطلوب بودن عبارات به لحاظ وضوح

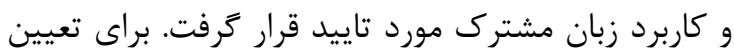

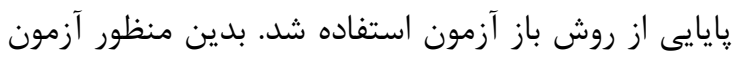

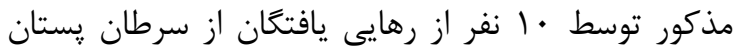

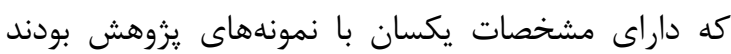

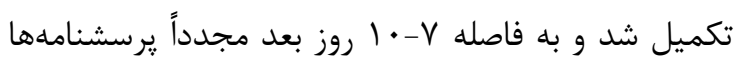
توسط همان افراد تكميل و سيس ضريب همبستتى آن

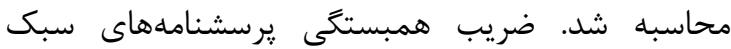

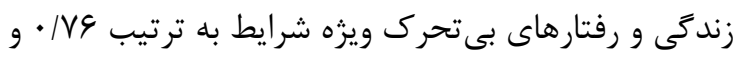

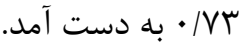
يرسشنامه سبك زندگى ^ (LSI) توسط ميلر - اسميت در در

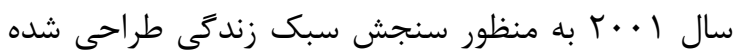

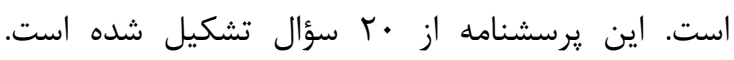

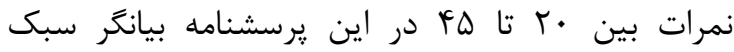

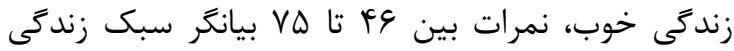

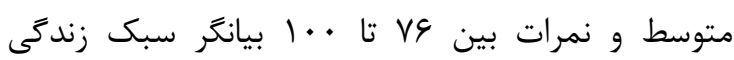
ناخوشايند و ناسالم است. فاضل و همكاران (•وسا)، روايى محتوايى يرسشنامه سبك زندگى را مطلوب ارزيابى

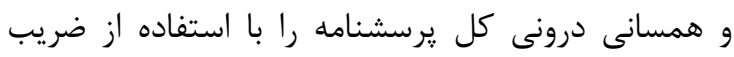
آلفاى كرونباخ ه内/ • بر آورد كردند (Tr). يك گروه از اين افراد در معرض فعاليت بدنى سبك قرار

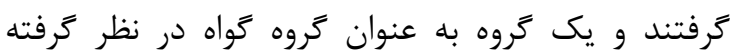

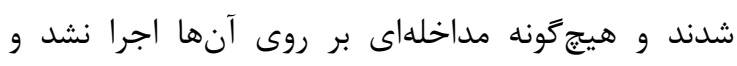

\footnotetext{
${ }^{8}$ Life Style Inventory
} 


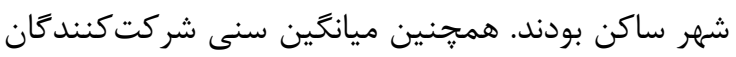

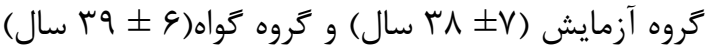

بود. - ماي

براى توصيف متغيرهاى مورد مطالعه، از شاخصهاى

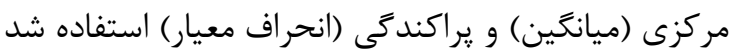
كه در جدول ( ) ارايه شده است.

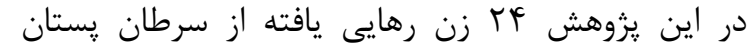

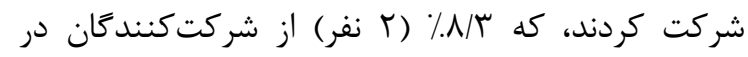

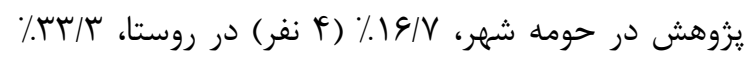

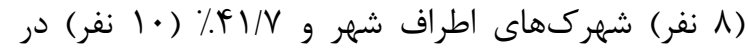

\begin{tabular}{|c|c|c|c|c|c|}
\hline \multicolumn{2}{|c|}{ 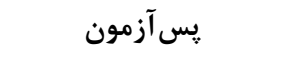 } & \multicolumn{2}{|c|}{ 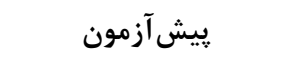 } & \multirow[b]{2}{*}{ تروه } & \multirow{2}{*}{ 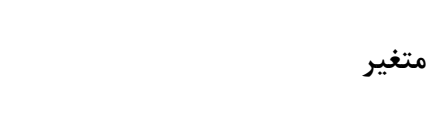 } \\
\hline انحراف معيار & ميانغين & انحراف معيار & ميانغين & & \\
\hline 9119 & rN/IG & $N / \Delta K$ & $\Delta F / \Delta \Lambda$ & آزمايش & \multirow{2}{*}{ تر ايش نسبت به بى تحركى } \\
\hline $1 \cdot 1 \cdot r$ & $\Delta \Delta / \Delta \cdot$ & $N / \Delta 9$ & $\Delta \Delta / \mathcal{F}^{\prime}$ & كواه & \\
\hline$\Delta / \cdot \Delta$ & $r \cdot / 91$ & $r / T V$ & $\mid F / V D$ & آزمايش & \multirow{2}{*}{ خودكار آمدى براى تسلط بر بى تحركى } \\
\hline f/vq & $r \cdot l \cdot \Lambda$ & $\Delta / F \Delta$ & $r N / \Delta \Lambda$ & كواه & \\
\hline$T / \cdot T$ & $V / 4)$ & T/AF & $10 / \Delta$ & آزمايش & \multirow{2}{*}{ ديدكاه شخص نسبت به بى تحركى } \\
\hline$r / \cdot r$ & $\mid \omega / T \Delta$ & T/FT & $19 / 0$ & كواه & \\
\hline I/Ar & $V / \Delta \Lambda$ & $r / \Delta \Lambda$ & $|\Delta / \Delta|$ & آزمايش & \multirow{2}{*}{ ديدكًاه اجتماعى نسبت به بى تحركى } \\
\hline ऍ/^৭ & $10 / V \mu$ & תس/T & $\mid \Delta / \cdot \Delta$ & كواه & \\
\hline$\Gamma / \Delta \Delta$ & $|\Delta / f|$ & $F / \Delta q$ & TN/VD & آزمايش & \multirow{2}{*}{ حمايت اجتماعى از بى تحركى } \\
\hline$f / r q$ & $r \cdot|f|$ & $f / 4 \varepsilon$ & $\Gamma / \Delta$. & كواه & \\
\hline$g|4|$ & $\Delta F / T \Delta$ & $q / F F$ & $91 / 94$ & آزمايش & \multirow{2}{*}{ الكوبردارى از بى تحركى در اوقات فراغت } \\
\hline $9 / 94$ & $9 \cdot 191$ & N/TG & $\Delta \Lambda / \Delta \Lambda$ & كواه & \\
\hline $19 / 48$ & $\mid r V / \Delta \Lambda$ & $19 / \mathrm{VV}$ & $r \cdot 9 / 91$ & آزمايش & \multirow{2}{*}{ عوامل شناختى - اجتماعى } \\
\hline TV/TA & $r \cdot \Delta / q 1$ & $|r| / 9 \mid$ & $r \cdot \Lambda / \Delta \Lambda$ & كواه & \\
\hline$N / \Delta \Delta$ & $|f q / 4|$ & $1 \cdot / 4$ & $s \pi / r \Delta$ & آزمايش & \multirow{2}{*}{ 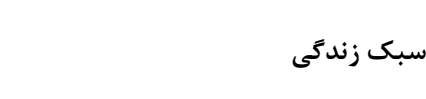 } \\
\hline$V / \Delta V$ & $0 \cdot 199$ & $\Delta / I V$ & $F \Delta / \mathcal{F}$. & كواه & \\
\hline
\end{tabular}

شده است.

نتايج تحليل كوواريانس جند نتايج نشان داد كه دست كم در يكى از مولفههاى عوامل شناختى - اجتماعى اثرخذار بر بع تحركى بين ميانگينهاى نمرات تفاوت معنى دار وجود

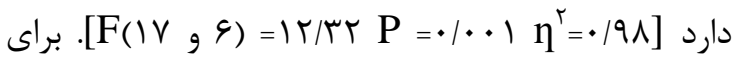
تعيين اين معنى دارى از نتايج تفكيكى تحليل كوواريانس

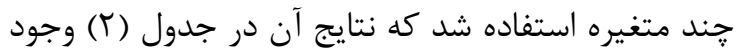

همانطور كه در جدول(r) مشاهده مى شود در متغيرهاى

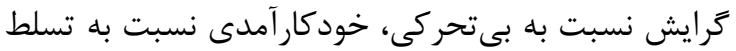
بر بى تحركى، هنجار متداول شخص نسبت به بى تحركى، هنجار اجتماعى نسبت به بى تحركى و حمايت اجتماعى از

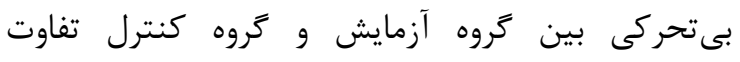
معنى دارى وجود دارد (P<0/05) ولى درهى دره متغير
همان گونه كه مندرجات جدول (1) نشان ميدهد،

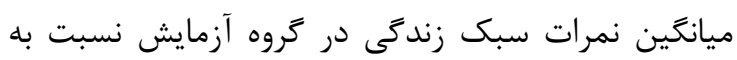
گروه گواه در مرحله يسآزمون افزايش يافته است و

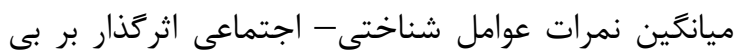

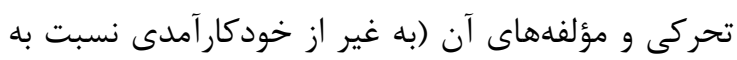

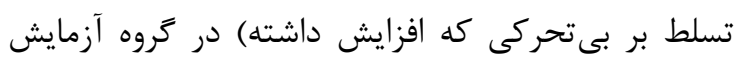

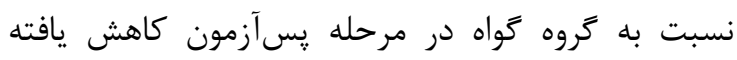

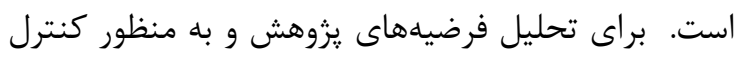
اثر پيشآزمون از تحليل كوواريانس استفاده گرديد.

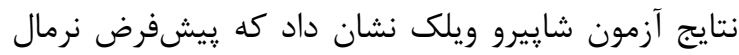

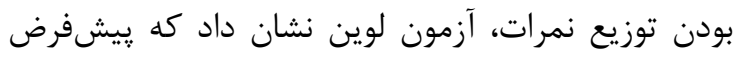

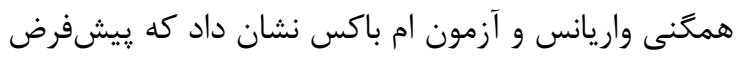

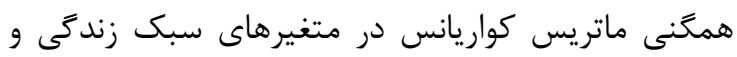

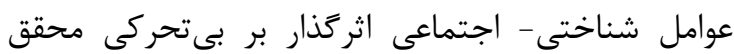




$$
\text { جدول (ب) ارايه شده است. }
$$

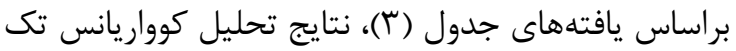

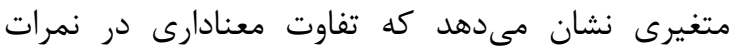

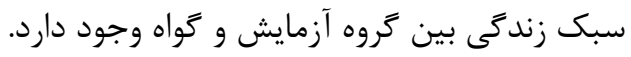

الكوبردارى از بىتحركى در اوقات فراغت بين كروهها

تفاوت معنى دار وجود ندارد.

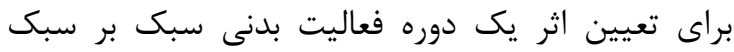

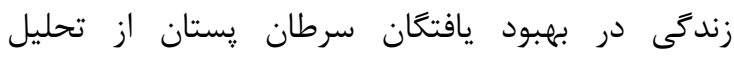

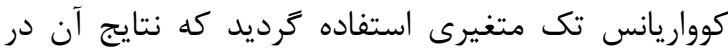

جدول r: نتايج تفكيك شده تحليل كوواريانس هند متغيرى براى عوامل شناختى-اجتماعى اثركذار بر بى تحركى

\begin{tabular}{|c|c|c|c|c|c|c|c|}
\hline مجذور & 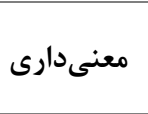 & $\boldsymbol{F}$ & مجذانكَين & دراديه & مجذورات & تغييرات & مؤلفهها \\
\hline \multirow{3}{*}{$\cdot / \Delta \Delta \Delta$} & 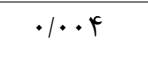 & $11 / r F$. & $\Delta / 9 / 1 \Delta 9$ & 1 & $\Delta / 9 / 1 \Delta 9$ & ي يشي آزمون & \multirow{3}{*}{ كرايش نسبت به بى تحركى } \\
\hline & $.1 \cdot 1$ & $r M / M$ & QVN/TAF & 1 & qVN/TAF & ك & \\
\hline & & & Fe/IAV & IV & $V \Delta N / I V \Lambda$ & خطا & \\
\hline \multirow{3}{*}{. } & .1 .94 & $9 / 914$ & $|\Delta r /| r s$ & 1 & $|\Delta T /| r g$ & ي بيشآزمون & \multirow{3}{*}{ خودكار آمدى براى تسلط بر بى تحركى } \\
\hline & $.1 \cdot 1$ & 19/0 & $T G \Psi / F \cdot V$ & 1 & TGT/DF.VG. & ك & \\
\hline & & & ID/QTT & iv & $r V \cdot / \Lambda r \Lambda$ & خطا & \\
\hline \multirow{3}{*}{$\cdot / 4 \mid r$} & $\cdot / \cdot \Delta V$ & $F / 19 \wedge$ & TF/ONT & 1 & TF/DAT & 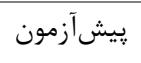 & \multirow{3}{*}{ بديدكاه متداول شخص نسبت به } \\
\hline & . & $11 / 94$ & $V \cdot / R T r$ & 1 & V V V V & og & \\
\hline & & & Q/A9A & iv & $1 \cdots / r 4$ & خطا & \\
\hline \multirow{3}{*}{ Trta } & $.1 \cdot r \Delta$ & $\Delta / T \& V$ & TV/DGA & 1 & $T V / \Delta \& \Lambda$ & بيش آزمون & \multirow{3}{*}{ ديدكًاه اجتماعى نسبت به بى تحركى } \\
\hline & . & $1 \% / 91$ & $91 / 190$ & 1 & $91 / 190$ & o & \\
\hline & & & $\Delta / T \Delta F$ & iv & $19 / \pi 19$ & خطا & \\
\hline \multirow{3}{*}{.1919} & $\%$. & $I T / F V V$ & $|\Delta \Delta / 9+|$ & 1 & $|Q \Delta / 9 T|$ & ي پيشآزمون & \multirow{3}{*}{ حمايت اجتماعى از بى تحركى } \\
\hline & $.1 \cdot 1$ & $T V / \Delta V$ & TFY/DGG & 1 & TYF/DGG & كرو & \\
\hline & & & $\mid r / F q V$ & IV & $r \mid r / f a r$ & خطا & \\
\hline \multirow{3}{*}{$.1 \cdot \varphi}$. & $.1 . \mu F$ & $\Delta / r \cdot G$ & $r q \cdot 1 \cdot \vee \wedge$ & 1 & $r q \cdot 1 \cdot \vee \wedge$ & بيش آزمون & \multirow{3}{*}{ فراغت الكوبردارى از بىتحركى در اوقات } \\
\hline &. $\mid 411$ & $\cdot|V|$ & $\uparrow N / 190$ & 1 & FN/ISD & كرو & \\
\hline & & & GVIAGY & IV & $\| \Delta \widetilde{Q} / 9 \Delta \Lambda$ & خطا & \\
\hline
\end{tabular}

جدول ؟ ب: نتايج تحليل كوواريانس تك متغيرى براى سبك زندكى

\begin{tabular}{|c|c|c|c|c|c|c|c|}
\hline مجذور ايتا & معنى دارى & $F$ & مجذانكين & دآزادى & مجذورات & منبع تغييرات & مؤلفهها \\
\hline \multirow{4}{*}{$\cdot \mid \Delta \Lambda}$. & .1111 & T/VAI & $\mid V q / r \cdot \Lambda$ & 1 & $1 V q / r \cdot 1$ & بيشآزمون & \multirow{4}{*}{ سبك زندكى } \\
\hline &.$/ . .1$ & $T V / \Delta V$ & IVVN/FHA & 1 & IVVN/FTA & ه & \\
\hline & & & $G F / F \wedge \Delta$ & $r$. & $1 Y \wedge 9 / 991$ & خطا & \\
\hline & & & & TF & VATES/.. & كل & \\
\hline
\end{tabular}

ديدكاه اجتماعى نسبت به بىتحركى و حمايت اجتماعى از

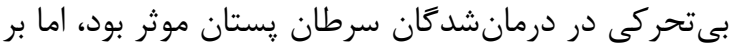

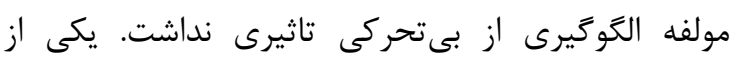
نتايج اين يزوهش نشان داد كه يك دوره فعاليت بدنى مدلهاى نظرى كه امروزه بيشتر براى شناخت فعاليت بدنى بزرگسالان از طريق درك عوامل كليدى رفتار مورد

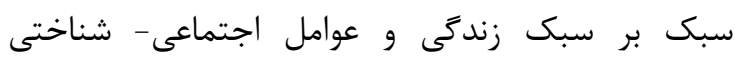
تاثيرگذار بر بىتحركى و مولفههاى آن شامل كرايش

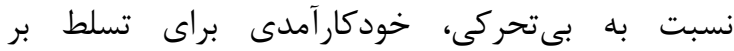

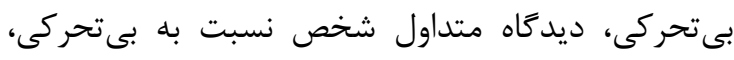


سبك زندگى بر خودكارآمدى در رهايى يافتكان سرطان

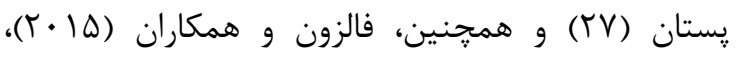
مبنى بر تصديق اثرات فعاليت بدنى بر خودكارآمدى زنان

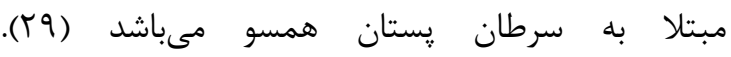
خودكارآهدى همواره به عنوان يكى از اجزاى مرتبط بان

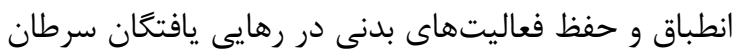
يستان مطرح بوده است (•r). مطابق با نظر بندورا

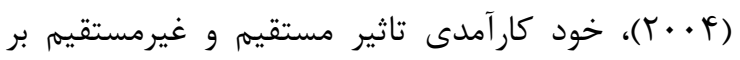

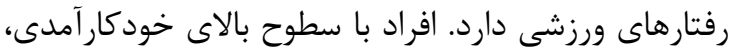
انتظارات مثبت بيشترى در زمينه رفتارهايى كه انجام

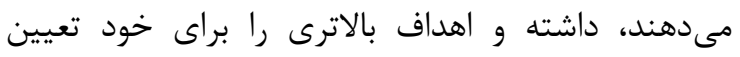
مى كنند و به احتمال قوى بر اين باور هستند كه قادر به داله

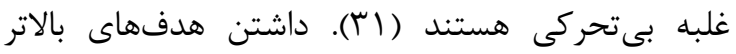

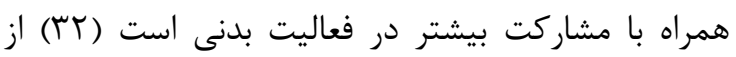
سوى ديخر خودكارآمدى به عنوان عامل تعيين كننده فعاليت بدنى خود از فعاليت بدنى تاثير مىيذيرد، به

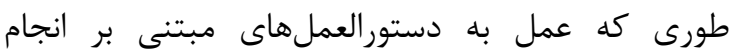
فعاليتبدنى سبك، با كاهش بىتحركى منجر به ارتقاى

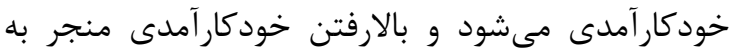
افزايش سطح فعاليت بدنى مى شود.

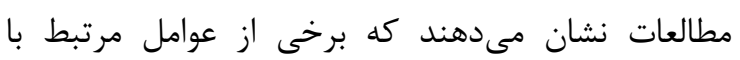

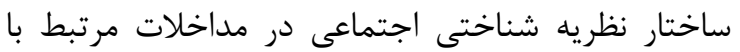
ارتقاى فعاليت بدنى مورد استفاده قرار مى گيرند (سبا). براى مثال، اصلاح انخيزههاى درونى شخص رونى رهايى يافته از

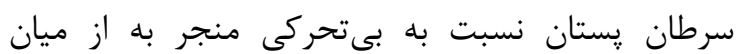

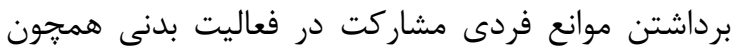

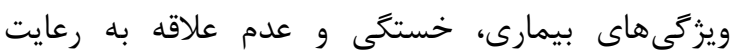

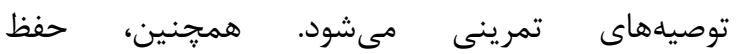
تسهيل كنندههاى فردى بالقوه فعاليتهاى بدنى از قبيل تصنيل تكميل كليه مراحل درمان و برخوردارى از سطوح بالاى

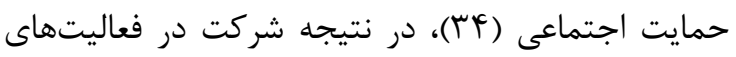

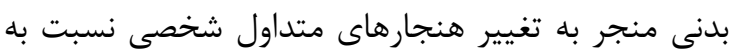
بى تحركى مىشود (ه山).

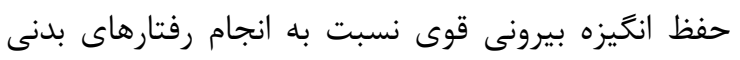

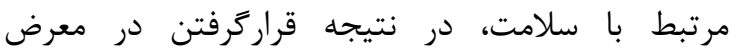
هنجارهاى اجتماعى متناسب با شركت در تمرينات ورزشى از سوى جامعه و اطرافيان حاصل مىشود (ه广).

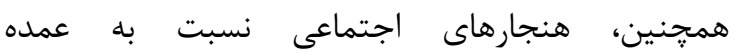
ييشبينى كنندهاى رفتارهاى بىتحرك در هنكام تماشاى
استفاده قرار مى گيرد، نظريه شناختى اجتماعى 'ا است

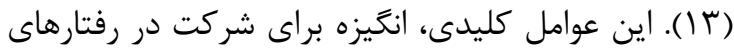

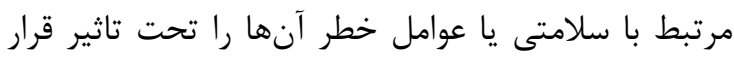

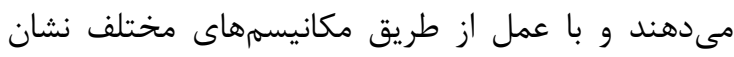
مىدهند كه عوامل شناختى اجتماعى مىتوانند تغييراتى در رفتارهاى بهداشتى مانند مشاركت در فعاليتهاى بدانى إنى إنى

يا كاهش رفتار بىتحرك ايجاد كنند (If).

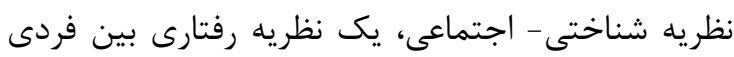
است، كه اثرات روانى اجتماعى را روى رفتار نشان مى دهد

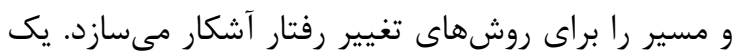
مفهوم كَترده از نظريه شناختى- اجتماعى تعيين كنندكى متقابل است كه وضعيت تعامل دائمى بين آنسين

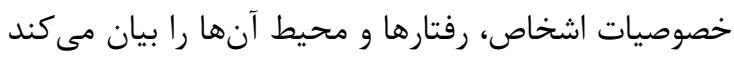
(TY)

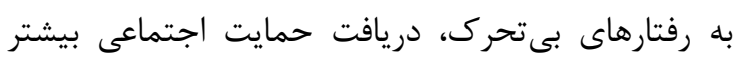
براى كم تحركى، عادت به بى بحركى بيشتر و همجنين،

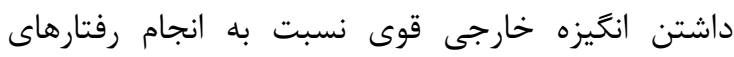

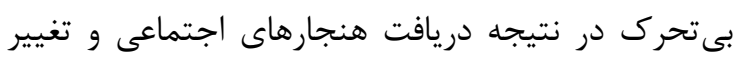
تمايلات متداول شخصى است (TQ T).

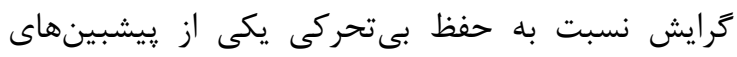

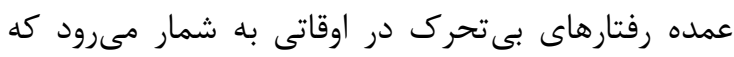
صرف تماشاى تلويزيون، استفاده از كامييوتر، بازىهاى

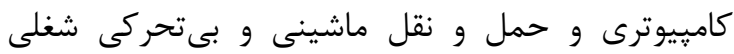

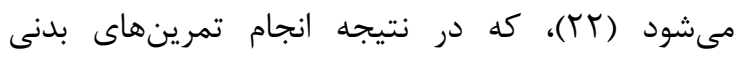
متناسب با نيازهاى فردى شخص بهرد (بهبود يافته با فواصل زمانى مشخص، افزايش تحرك و عملكرد بدنى، كاهش بـ بردي

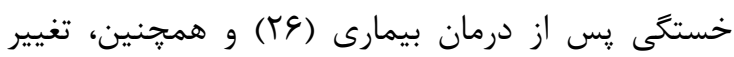

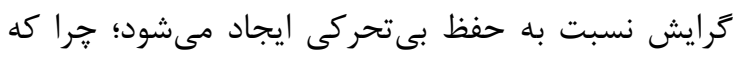
تحقيقات موجود نشان مىدهد كه بهبود يافتكان سرطان بـان

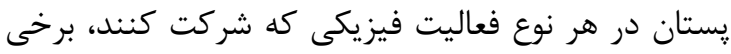

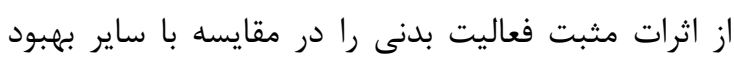

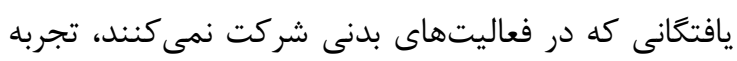

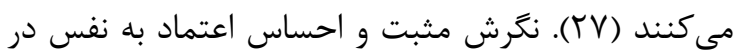

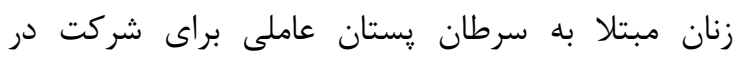

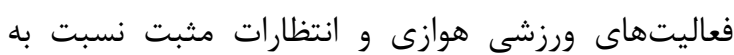
اجراى فعاليتهاى بدنى مىشود (T^).

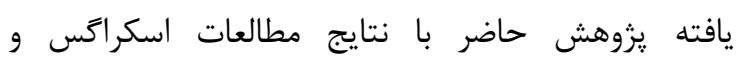

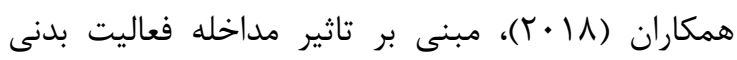

\footnotetext{
${ }^{12}$ Social Cognitive Theory
} 
(آمريكايى - مكزيكى تبار در مقابل زنان ايرانى) نسبت داد؛

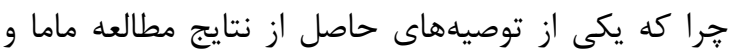

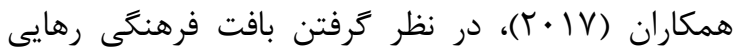
يافتكان سرطانى در تعيين تغييرات عوامل شناختى درفي

اجتماعى بر اثر فعاليت بدنى بود (ه (1).

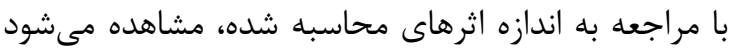

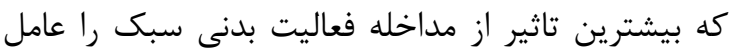

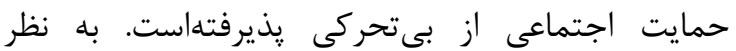
مىرسد كه اين مداخله منجر به تغيير ديدكاه اطرافيان و

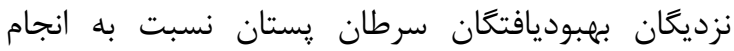
فعاليت بدنى شده است و توانسته حمايت اجتماعى از بران

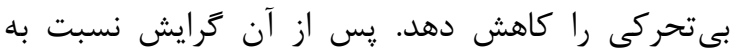

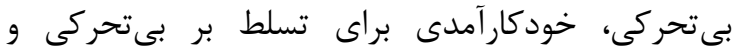

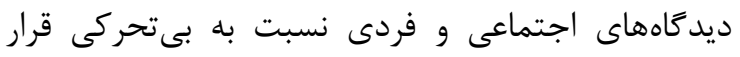

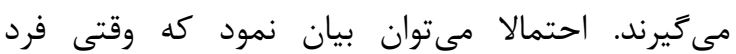

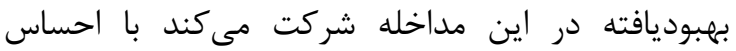

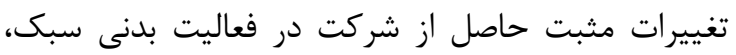
ديدَاه و تمايلش براى شركت در فعاليت بدنى سبك ديك افزايش پِيدا كرده است. نتايج تحليل كواريانس تك متغيرى نشان داد كه يك دوره

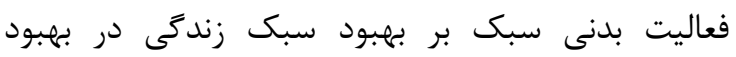

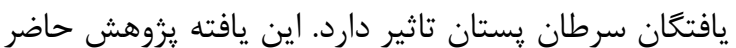

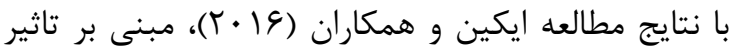
مداخله تغيير سبك زندگى (در زمينه فعاليت بدنى، تغذيه

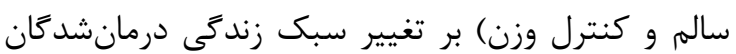

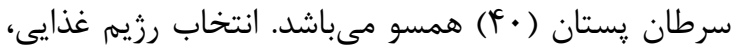

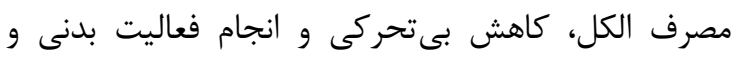

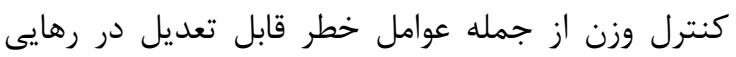
يافتكان سرطان يستان به شمار مىروند (أl|l). بهببود سبك زندگى سالم (به عنوان مثال، تحرك بيشتر و ونان

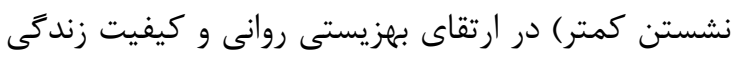
بهبوديافتكان سرطان يستان بسيار مهرم است (F) (F). همجنين مداخلات فعاليت بدنى مىتوانند باعث به حداقل

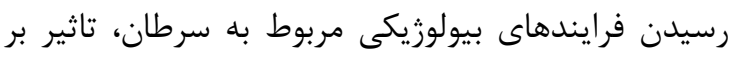
رفتارى كه باعث به حداقل رسيدن عوامل خطرساز سبك بريك زندگى براى بروز مجدد سرطان و بهبود فاكتورهاى روانى اجتماعى در طول و يس از درمان سردان سرطان شوند. بنابراين، به نظر مى رسد كه مداخله فعاليت بدنى سبك استفاده دران شده در تحقيق حاضر با بهبود ايجاد كردن در كيفيت برداني
تلويزيون، استفاده از كامييوتر و تلفن همراه و رفت و آمد با وسايل نقليه و رفتارهاى بىتحرى كاهش مىيايد، كه اين امر در نتيجه انجام دستورالعملهاى مرتبط بال بال فعاليتهاى بدنى متوسط تا شديد در زنان رهايى يافته از سرطان קستان حاصل مىشود كه در برخى از مطالعات مورد تاييد قرار گرفته است (צ (؟).

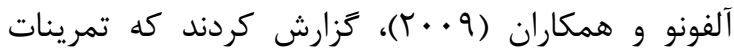

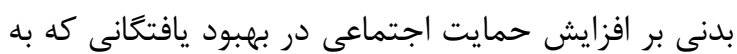

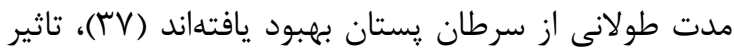

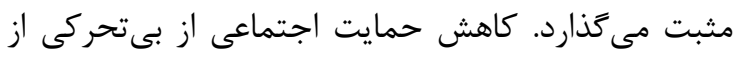

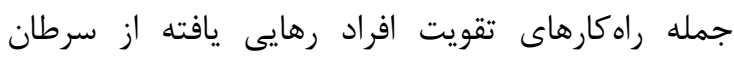

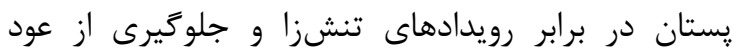

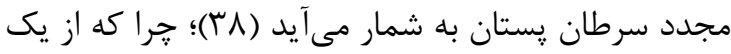
سو، سيستمهاى حمايت اجتماعى با ترغيب بيماران به

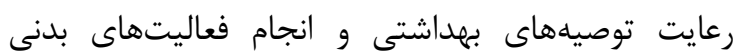
مىتوانند آثار و ويامدهاى منفى بىتحركى بر وضعيت بهايت

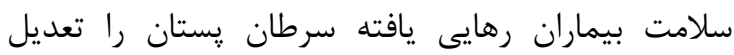

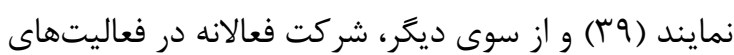
بدنى سبك و كاهش كم تحركى منجر به ارتقاى حمايت

اجتماعى به منظور شركت در تمرينات بدنى مى

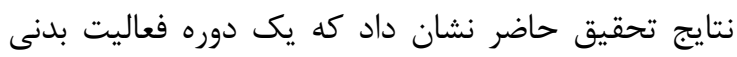
سبك بر كاهش الكوبردارى از بى تحركى در بهببود يافتيان

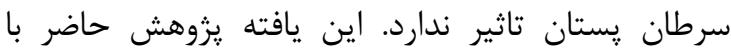

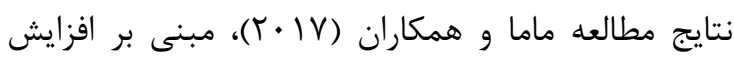

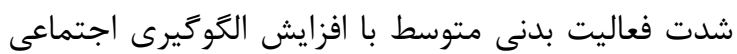
نسبت به فعاليت بدنى و كاهش رفتارهاى بىتحرك در بهبود يافتكان سرطان يستان اسيانيايى (ل|) مخالف

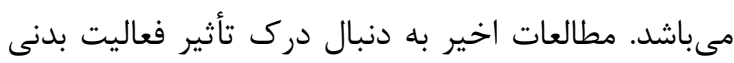
بر الكوبردارى اجتماعى در رهايى يافتخان سرطان يستان

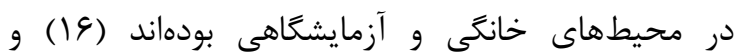

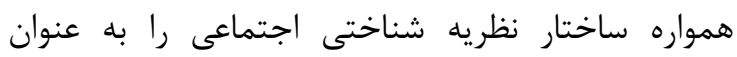
تعيينكنندهاى فعاليت بدنى در ميان رهايى يافتكان إنىان إنىان

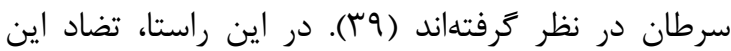
يافته يزوهش حاضر با نتايج مطالعه ماما و همكاران

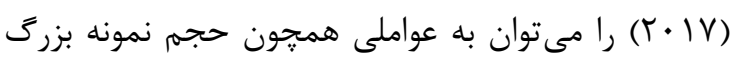

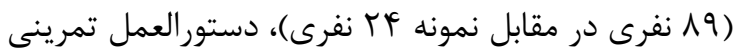

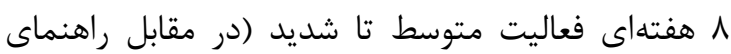

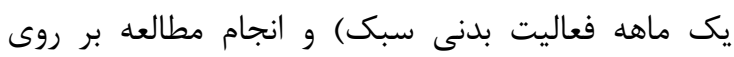

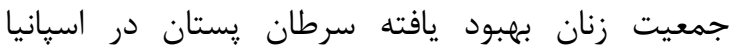


از سرطان سينه را تغيير دهيم. كه به نظر مىرسد با تاكيد و ايجاد مداخله جهت تغيير عوامل اجتماعى شناختى رئى رئه اثرگذار بر بى تحركى مى توان به اين مساله نزديك شد. اما

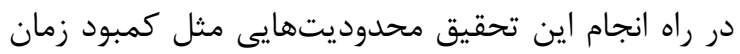

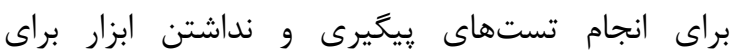
اندازهيرى عينى سطح فعاليت بدنى مشاركت كنندهها وجود داشت كه توصيه مىشود در تحقيقات آينده اين موارد برطرف شود. ييشنهاد مىشود كه دورههايى مبتنى بر انجام فعاليت بدنى سبك متناسب با نيازهاى فردى رهايى يافتگان سرطان يستان با هدف بهبود سبك زندگى و كاهش بى تحركى در كلينيكهاى تخصصى تدوين گردد بـ يا دستورالعملهاى فعاليتهاى بدنى سبك، براى استفاده رهايى يافتخان سرطان يستان در دورههاى طولانى مدت

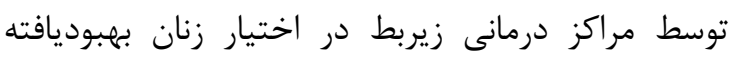
سرطان پِنتان قرار گيرد.

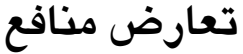

نويسند يزوهش حاضر وجود ندارد.

\section{References}

1. American Cancer Society. Breast cancer facts \& figures, 2005-2006. Atlanta: American Cancer Society, Inc. (http://www.cancer.org/).

2. Tavakoliyan L, Bonyadi F, Malekzadeh E. The investigation of factors associated with breast cancer screening among Kazeroon women aged 20-65 in 2013. NJV. 2015; 1(1):17-31.

3. Kushi LH, Kwan ML, Lee MM, Ambrosone CB. Lifestyle factors and survival in women with breast cancer. JN. 2007; 137(1):236-42.

4. DeNysschen C, Brown JK, Baker M, Wilding G, Tetewsky S, Cho MH, Dodd MJ. Healthy lifestyle behaviors of breast cancer survivors. CNR. 2015; 24(5): 50425.

5. Kerr J. Community health promotion: challenges for practice. Baillière Tindall; $1^{\text {st }}$ Edition. UK. 2000; 128.

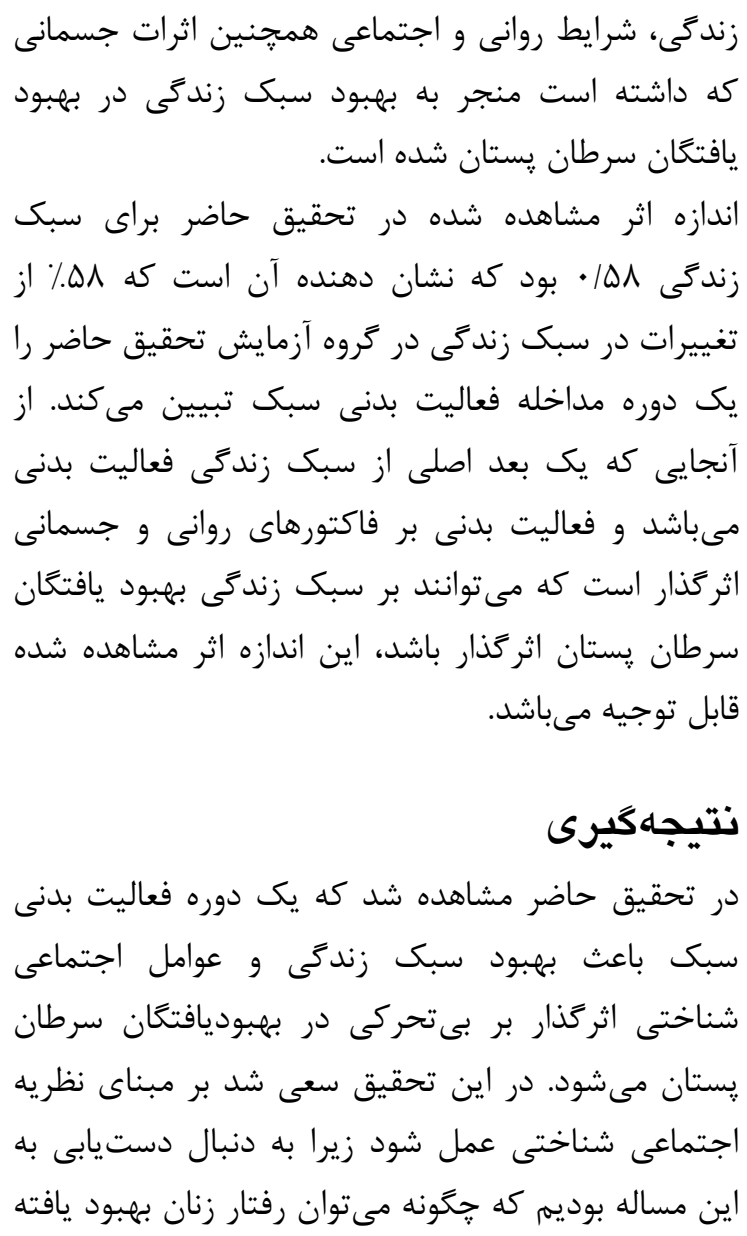

6. Boyle T, Vallance JK, Ransom EK, Lynch BM. How sedentary and physically active are breast cancer survivors, and which population subgroups have higher or lower levels of these behaviors?. SCC. 2016; 24(5):2181-90.

7. Lynch BM, Boyle T, Winkler E, Occleston J, Courneya KS, Vallance JK. Patterns and correlates of accelerometer-assessed physical activity and sedentary time among colon cancer survivors. CCC. 2016; 27(1):59-68.

8. Barnes J, Behrens TK, Benden ME, Biddle S, Bond D, Brassard P, Brown H, Carr L, Chaput JP, Christian H, Colley R. Letter to the Editor: Standardized use of the terms" sedentary" and "sedentary behaviours". Applied Physiology NMPh. 2012; 37(3): 540-2.

9. Colley RC, Garriguet D, Janssen I, Craig CL, Clarke J, Tremblay MS. Physical activity of Canadian adults: accelerometer 
results from the 2007 to 2009 Canadian Health Measures Survey. HR. 2011; 22(1):7.

10. Matthews CE, Chen KY, Freedson PS, Buchowski MS, Beech BM, Pate RR, Troiano RP. Amount of time spent in sedentary behaviors in the United States, 2003-2004. AJE. 2008; 167(7):875-81.

11. Lynch BM, Dunstan DW, Vallance JK, Owen N. Don't take cancer sitting down: a new survivorship research agenda. C. 2013; 119(11):1928-35.

12. Matthews CE, George SM, Moore SC, Bowles HR, Blair A, Park Y, Troiano RP, Hollenbeck A, Schatzkin A. Amount of time spent in sedentary behaviors and cause-specific mortality in US adults. AJCN. 2012; 95(2):437-45.

13. Bandura A. Self- efficacy: The exercise of control. New York, NY, US: W H Freeman/Times Books/ Henry Holt \& Co. 1997; 112.

14. Fjeldsoe BS, Miller YD, Marshall AL. Social cognitive mediators of the effect of the MobileMums intervention on physical activity. HPsy. 2013; 32(7):729.

15. Mehrabani F, Mehrabani J. Evaluation of the Level of Physical Activity, Physical Fitness, Obesity, and Musculoskeletal Abnormalities in University Students. TJPM. 2016; 2(3):33-43.

16. Mama SK, Song J, Ortiz A, Tirado-Gomez M, Palacios C, Hughes DC, Basen-Engquist K. Longitudinal social cognitive influences on physical activity and sedentary time in Hispanic breast cancer survivors. PsyO. 2017; 26(2): 214-21.

17. Short CE, James EL, Plotnikoff RC. How Social Cognitive Theory can help oncology-based health professionals promote physical activity among breast cancer survivors. EJON. 2013; 17(4):4829.

18. Eakin EG, Hayes SC, Haas MR, Reeves MM, Vardy JL, Boyle F, Hiller JE, Mishra GD, Goode AD, Jefford M, Koczwara B. Healthy Living after Cancer: a dissemination and implementation study evaluating a telephone-delivered healthy lifestyle program for cancer survivors. BMCC. 2015; 15(1):992.

19. PourRanjbar M, Amiri-Moghaddam M, Ghadimi B. The Relationship between Breast Cancer and Lifestyle based on
Cockerham and Bourdieu Theory: a study on Kerman women. JHD. 2016; 5(3):238256.

20. Khosravi P, Moradi A, Jenabian A. The effects of cognitive theraphy based on mindfulness on decreasing the symptom of post-traumatic stress disorder and increasing the autobiographical memory in treated patients with breast cancer. CCPsy. 2014; 5(18):51-67.

21. Busschaert C, De Bourdeaudhuij I, Van Holle V, Chastin SF, Cardon G, De Cocker K. Reliability and validity of three questionnaires measuring context-specific sedentary behaviour and associated correlates in adolescents, adults and older adults. IJBNPA. 2015; 12(1):117.

22. Busschaert C, Ridgers ND, De Bourdeaudhuij I, Cardon G, Van Cauwenberg J, De Cocker K. Sociodemographic, social-cognitive, healthrelated and physical environmental variables associated with context-specific sitting time in Belgian adolescents: a oneyear follow-up study. PO. 2016; 11(12):123.

23. Fazel A, Haghshenas H, Keshavarz Z. Ability to predict personality traits and lifestyle on women's satisfaction nurse city couple. QJWS. 2011; 2(7):139-63.

24. Gaines A, Turner LW. Improving Fruit and Vegetable Intake among Children: A Review of Interventions Utilizing the Social Cognitive Theory. CJHP. 2009; 7(1):52-66.

25. Rogers LQ, Matevey C, Hopkins-Price P, Shah P, Dunnington G, Courneya KS. Exploring social cognitive theory constructs for promoting exercise among breast cancer patients. CN. 2004; 27(6):462-73.

26. Pinto BM, Trunzo JJ, Reiss P, Shiu SY. Exercise participation after diagnosis of breast cancer: trends and effects on mood and quality of life. Psycho-Oncology: JPSBDC. 2002; 11(5):389-400.

27. Scruggs S, Mama SK, Carmack CL, Douglas T, Diamond P, Basen-Engquist K. Randomized Trial of a Lifestyle Physical Activity Intervention for Breast Cancer Survivors: Effects on Transtheoretical Model Variables. HPP. 2018; 19(1):134-44.

28. McNeely ML, Campbell KL, Rowe BH, Klassen TP, Mackey JR, Courneya KS. Effects of exercise on breast cancer patients and survivors: a systematic review and meta-analysis. CMAJ. 2006; 175(1):34-41. 
29. Falzon C, Radel R, Cantor A, d'ArripeLongueville $\mathrm{F}$. Understanding narrative effects in physical activity promotion: the influence of breast cancer survivor testimony on exercise beliefs, self-efficacy, and intention in breast cancer patients. SCC. 2015; 23(3):761-8.

30. Rogers LQ, Shah P, Dunnington G, Greive A, Shanmugham A, Dawson B, Courneya KS. Social cognitive theory and physical activity during breast cancer treatment. ONF. 2005; 32(4):807-15.

31. Bandura A. Health promotion by social cognitive means. HEB. 2004; 31(2):143-64.

32. Dishman RK, Vandenberg RJ, Motl RW, Wilson MG, DeJoy DM. Dose relations between goal setting, theory-based correlates of goal setting and increases in physical activity during a workplace trial. HER. 2009; 25(4):620-31.

33. Pinto BM, Ciccolo JT. Physical activity motivation and cancer survivorship. PAC. Springer, Berlin, Heidelberg. 2010; 367-87.

34. Courneya KS, Katzmarzyk PT, Bacon E. Physical activity and obesity in Canadian cancer survivors: population-based estimates from the 2005 Canadian Community Health Survey. CIIJACS. 2008; 112(11):2475-82.

35. Rollo S, Gaston A, Prapavessis H. Cognitive and motivational factors associated with sedentary behavior: A systematic review. AIMSPH. 2016; 3(4): 956-84.

36. Friberg E, Mantzoros CS, Wolk A. Physical activity and risk of endometrial cancer: a population-based prospective cohort study. CEPB. 2006; 15(11): 213640.

37. Alfano CM, Day JM, Katz ML, Herndon JE, Bittoni MA, Oliveri JM, Donohue K,
Paskett ED. Exercise and dietary change after diagnosis and cancer-related symptoms in long-term survivors of breast cancer: CALGB 79804. Psycho-Oncology: JPSBDC. 2009; 18(2):128-33.

38. Pinto BM, Papandonatos GD, Goldstein MG, Marcus BH, Farrell N. Home-based physical activity intervention for colorectal cancer survivors. PO. 2013; 22(1):54-64.

39. Pinto BM, Rabin C, Dunsiger S. Home-based exercise among cancer survivors: adherence and its predictors. Psycho-Oncology: JPSBDC. 2009; 18(4):369-76.

40. Eakin EG, Hayes SC, Haas MR, Reeves MM, Vardy JL, Boyle F, Hiller JE, Mishra GD, Goode AD, Jefford M, Koczwara B. Healthy Living after Cancer: a dissemination and implementation study evaluating a telephone-delivered healthy lifestyle program for cancer survivors. BMCC. 2015; 15(1):992-1003.

41. Kushi LH, Doyle C, McCullough M, Rock CL, Demark-Wahnefried W, Bandera EV, Gapstur S, Patel AV, Andrews K, Gansler T, American Cancer Society 2010 Nutrition and Physical Activity Guidelines Advisory Committee. American Cancer Society Guidelines on nutrition and physical activity for cancer prevention: reducing the risk of cancer with healthy food choices and physical activity. CACJC. 2012; 62(1):3067.

42. O'Neill SC, DeFrank JT, Vegella P, Richman AR, Henry LR, Carey LA, Brewer NT. Engaging in health behaviors to lower risk for breast cancer recurrence. PO. 2013; 8(1):1-7. 